\title{
PELATIHAN PEMBUATAN BAHAN AJAR BERBASIS MULTIMEDIA BAGI GURU-GURU AL YASINI PASURUAN
}

\author{
Muhammad Khudzaifah $^{1}$, Hawzah Sa' adati $^{2}$ \\ ${ }^{1,2}$ Jurusan Matematika, UIN Maulana Malik Ibrahim Malang \\ khudzaifah@uin-malang.ac.id,hawzahsaadati@gmail.com
}

\begin{tabular}{l} 
Info Artikel \\
\hline Riwayat Artikel: \\
Diterima: September 2019 \\
Direvisi: Januari 2020 \\
Diterbitkan: Maret 2020 \\
\end{tabular}

Keywords:

Learning

Multimedia

Al Yasini Pasuruan

\begin{abstract}
Multimedia provides opportunities for educators to develop learning techniques so as to produce maximum results, with multi media it is hoped that they will be easier to determine with what and how students can absorb information quickly and efficiently. Until now, interactive learning media has not been developed optimally in Indonesia. One obstacle in the development of interactive learning media is the lack of mastery of interactive media development technology by teachers, so the development of interactive learning materials with computers is less than optimal. This online-based learning media development training that will be developed and applied for teachers at the Al Yasini Pasuruan Foundation is expected to provide new insights in making instructional media, given the ability of this program in terms of making animations for attractive online-based learning media in a relatively easy way. With the mastery of online-based learning media by the teachers at the $\mathrm{Al}$ Yasini Pasuruan Foundation, it is hoped that it will trigger students' interest to be more enthusiastic in following the lessons, and ultimately will improve the overall quality of learning.
\end{abstract}

Copyright $(2020$ JRCE. All rights reserved.

\author{
Korespondensi: \\ Muhammad Khudzaifah, \\ Jurusan Matematika, \\ UIN Maulana Malik Ibrahim Malang, \\ Jl. Gajayana No. 50 Malang, Jawa Timur, Indonesia 65144 \\ khudzaifah@uin-malang.ac.id
}

\section{PENDAHULUAN}

Multimedia menyediakan peluang bagi pendidik untuk mengembangkan teknik pembelajaran sehingga menghasilkan hasil yang maksimal. Demikian juga bagi pelajar, dengan multi media diharapkan mereka akan lebih mudah untuk menentukan dengan apa dan bagaimana siswa untuk dapat menyerap informasi secara cepat dan efisien.

Sampai saat ini media pembelajaran interaktif belum berkembang dengan optimal di Indonesia. Salah satu kendala pengembangan media pembelajaran interaktif adalah kurang dikuasainya teknologi pengembangan media interaktif oleh para pengajar, sehingga pengembangan materi pembelajaran interaktif dengan komputer kurang optimal.

Membuat bahan ajar bagi guru sudah merupakan hal biasa. Tetapi bagaimana dengan membuat bahan ajar berbasis web offline? Itu merupakan suatu hal yang menakutkan bagi banyak guru dan dosen. Mendengar bahan ajar berbasis web offline maka akan terlintas seorang guru atau dosen harus memiliki kemampuan membuat web, memahami bahasa pembuatan web yaitu HyperText Markup Language (HTML) adalah sebuah bahasa markup yang digunakan untuk membuat sebuah halaman web, menampilkan berbagai 
informasi di dalam sebuah Penjelajah web Internet dan formating hypertext sederhana yang ditulis kedalam berkas format ASCII agar dapat menghasilkan tampilan wujud yang terintegerasi. Tetapi jangan khawatir, anda sebagai guru atau dosen tidak perlu alergi dengan belajar membuat bahan ajar berbasis web online, walaupun anda tidak mengetahui dan tidak memahami apa itu bahasa pemrograman HTML. Pada laporan akan diberikan solusi untuk membuat bahan ajar berbasis web offline dengan sangat sederhana yaitu menggunakan program pengolah kata Microsoft Word, maka guru dapat membuat bahan ajar tersebut.

Berdasar berbagai kondisi tersebut, kegiatan pelatihan ini sangat penting untuk diadakan. Pelatihan pengembangan media pembelajaran berbasis online dengan pemanfaatan program pengolah kata Microsoft Word yang akan dikembangkan dan diterapkan bagi para guru di Yayasan Al Yasini Pasuruan ini diharapkan akan memberikan wawasan baru dalam pembuatan media pembelajaran, mengingat kemampuan program ini dalam hal pembuatan animasi untuk media pembelajaran berbasis online yang menarik dengan cara yang relatif mudah. Dengan dikuasainya media pembelajaran berbasis online oleh para guru di Yayasan Al Yasini Pasuruan diharapkan akan pemicu minat siswa untuk lebih bersemangat dalam mengikuti pelajaran, dan pada akhirnya akan meningkatkan kualitas pembelajaran secara keseluruhan.

Lembaga yang menjadi sasaran kegiatan kali ini adalah di Yayasan Al Yasini Pasuruan yang telah memiliki laboratorium komputer yang lengkap, sehingga dapat diasumsikan bahwa penggunaan komputer dalam proses belajar mengajar sudah sangat familiar. Disamping itu yang menjadi pertimbangan lain adalah pihak guru-guru di Yayasan Al Yasini Pasuruan telah mengajukan permohonan agar dilatih untuk membuat media pembelajaran interaktif dengan pemanfaatan program pengolah kata Microsoft Word dan Microsoft Power Point, sehingga pelatihan yang akan diadakan ini benar-benar sesuai dengan kebutuhan sekolah yang menjadi sasaran pengabdian.

\section{METODE PENELITIAN}

Metode yang akan diterapkan dalam kegiatan ini adalah pelatihan dan praktek langsung. Dalam pelatihan ini akan diberikan beberapa kegiatan yang meliputi penyajian materi, dan praktik pembuatan media oleh para guru peserta pelatihan. Selanjutnya media pembelajaran yang telah dikerjakan oleh para guru dipresentasikan di depan kelas untuk saling memberikan masukan demi perbaikan media pembelajaran yang telah dibuat.

Langkah-langkah Kegiatan PPM

Adapun langkah yang akan ditempuh dalam kegiatan PPM kali ini mencakup beberapa tahap berikut ini. 1. Persiapan

Tahap persiapan merupakan tahap awal sebelum pelaksanaan PPM. Dalam tahap ini ada beberapa hal yang dilakukan:

a. Koordinasi Internal, dilakukan oleh Tim untuk merencanakan pelaksanaan

b. Penentuan dan rekruitment peserta pelatihan

c. Pembuatan Instrumen PPM, seperti lembar presensi, angket, lembar kerja

d. Pembuatan modul pelatihan Microsoft Word

e. Persiapan konsumsi, publikasi, lokasi, dokumentasi, dsb.

2. Pelaksanaan Pelatihan

Tahap ini merupakan tahap pelatihan yang diberikan kepada para guru Yayasan Al Yasini Pasuruan. Pelaksanaan pelatihan ini mencakup beberapa hal berikut.

a. Penyajian Materi

Materi yang disajikan terkait dengan pengenalan dan penggunaan program Microsoft Word untuk pembuatan media pembelajaran. Penyajian ini diploting dalam satu kali tatap muka. Penyaji materi adalah tim pengabdi sendiri disesuaikan dengan bidang keahlian masing-masing.

b. Penugasan Praktik

Pada akhir materi peserta akan diberi tugas praktik sesuai materi yang telah disajikan untuk menggali penyerapan dan pemahaman materi serta melihat kreativitasnya dalam berkarya. Dalam pelatihan ini para guru ditugaskan untuk membuat satu media pembelajaran terkait mata pelajaran yang diampu masing-masing guru. Tim pengabdi mendampingi, memandu dan mengarahkan serta memberikan solusi apabila timbul permasalahan selama penugasan praktik.

c. Refleksi dan Penutupan Program PPM

Di akhir kegiatan peserta dan Tim melakukan refleksi hasil pelatihan dan para peserta juga memberikan evaluasi akan pelatihan ini. Peserta dapat melihat secara langsung hasil media yang telah dikerjakan serta membandingkan hasil sebelum dan sesudah kegiatan. Setelah semua kegiatan yang telah direncanakan terlaksana, ketua tim PPM menutup program dan memberikan pesan kepada segenap peserta pelatihan untuk menerapkan apa yang telah didapatkan untuk memperbaiki media pembelajaran di sekolah masing-masing. Diharapkan pada PPM yang akan akan datang program ini dapat dilanjutkan lagi dan dapat lebih menjangkau 
jumlah sekolah lain tak hanya satu lembaga saja, sehingga kebermanfaatan program ini dapat dirasakan oleh sekolah yang lebih banyak.

3. Evaluasi Kegiatan

Evaluasi kegiatan PPM ini dilakukan dengan beberapa cara. Evaluasi hasil dilihat dari tugas praktik para peserta yang ada. Hasil praktiknya dinilai dan hal itu menggambarkan keberhasilan materi yang telah disajikan. Selain itu, secara proses juga dicermati kinerja dan kesertaan para peserta. Di akhir kegiatan Tim menjaring data kebermaknaan program pada para peserta.

\section{HASIL DAN PEMBAHASAN}

Guru merupakan salah satu yang menggerakkan pendidikan di Indonesia. Namun, tanpa wawasan yang selalu dikembangkan dan di-up grade maka guru akan makin ketinggalan di era sekarang. Apalagi kebutuhan siswa juga makin berkembang. Lebih lagi, pemanfaatan teknologi di kalangan guru masih dianggap memprihatinkan. Kondisi ini dipengaruhi juga oleh kurangnya fasilitas penunjang pengembangan teknologi pembelajaran disamping sumber daya manusia yang menguasai teknologi masih kurang memadai.

Pelatihan ini memberikan beberapa materi yang terkait dengan upaya mengembangkan media pembelajaran interaktif agar pembelajaran yang diberikan oleh guru menjadi lebih atraktif sehingga meningkatkan minat dan kualitas belajar siswa. Materi yang disajikan oleh pengabdi dapat diterima, dicerna, dan dipahami peserta dengan baik. Jumlah peserta yang sebanding dengan jumlah pengabdi yang berperan sebagai instruktur dan tutor menjadikan pelatihan ini menjadi lebih kondusif. Hal ini didukung pula dengan kemampuan peserta di bidang komputer telah cukup memadai karena pada proses perekrutan telah ditetapkan standar minimal peserta telah menguasai komputer dasar sehingga pelatihan dapat berjalan lancar dan para peserta dapat berkomunikasi dengan para pembicara dan peserta lain dengan lebih baik.

Kegiatan tanya jawab dilakukan bersamaan dengan penyajian materi. Para peserta dapat langsung berdiskusi dengan para pemateri secara langsung untuk memahamkan materi dan sharing pengalaman terkait dengan masalah yang tengah dibahas dalam materi bersangkutan. Kegiatan ini terlaksana di ruang kelas Yayasan Al Yasini Pasuruan yang cukup representatif. Kegiatan ini dihadiri 47 peserta guru dari berbagai bidang mata pelajaran.

Peserta dan pemateri terlibat aktif dalam penyusunan dan penyempurnaan slide yang dibuat oleh peserta. Pemateri dibantu oleh beberapa rekan mengamati satu persatu hasil desain presentasi oleh peserta.Dalam sesi ini tidak jarang muncul beberapa ide kreatif dari peserta. Ide-ide tersebut berangkat dari masalah yang sering dihadapi saat proses kegiatan belajar mengajar di kelas berlangsung. Beberapa kendala dan masalah yang ditemui dalam pengajaran tanpa menggunakan PowerPoint banyak didiskusikan untuk dipecahkan.

Pembuatan slide presentasi dimulai dari yang paling sederhana, diantaranya: 1) Penyisipan gambar, audio, dan video; 2) Konversi list menjadi SmartArt; 3) Teknik layering dalam memunculkan tiap baris konten slide secara bertahap; 4) Beberapa animasi teks dan transisi slide dasar; serta 5) Navigasi antar slide menggunakan mouse maupun shortcut.

Tahap terakhir program pelatihan ini adalah evaluasi. Evaluasi dilakukan pada pertemuan ke dua pada hari yang berbeda. Pada pertemuan kedua ini para peserta pelatihan menunjukkan slide presentasi hasil karyanya yang merupakan PR dari pertemuan sebelumnya. Beberapa dari slide presentasi tersebut dipresentasikan di depan kelas. Karena keterbatasan waktu, slide presentasi peserta lain tidak dipresentasikan di depan kelas. Presentasi tersebut diperiksa oleh pemateri dan tim di laptop masing-masing peserta latihan.

Evaluasi kegiatan PPM ini dilakukan dengan beberapa cara. Evaluasi hasil dilihat dari tugas praktik para peserta yang ada. Hasil praktiknya dinilai dan hal itu menggambarkan keberhasilan materi yang telah disajikan. Selain itu, secara proses juga dicermati kinerja dan kesertaan para peserta. Di akhir kegiatan Tim menjaring data kebermaknaan program pada para peserta. Berdasarkan hasil produk berupa media pembelajaran interaktif dengan program Powerpoint, secara umum para peserta telah mengetahui dasar-dasar penggunaan proram dan telah mampu menerapkannya dalam pembutan media, terbukti dengan nilai rata-rata yang dicapai oleh peserta rata-rata B (Baik).

Berdasarkan penilaian dapat dilihat bahwa rata-rata guru peserta pelatihan telah mampu menerapkan program Powerpoint ini untuk membuat media pembelajaran, dengan dikuasainya point-point kompetensi dalam penguasaan. Program Powerpoint yang telah ditetapkan sebagai instrument penilaian, yakni: Pengenalan Materi dan Tools Powerpoint, Memasukkan Teks dan Gambar, Memasukkan Suara dan Video, Membuat background, Mengatur effect, order dan timing, Membuat Hyperlink antar slide, Membuat Hyperlink ke URL, dan diakhiri dengan praktek langsung Pembuatan Media Pembelajaran Interaktif dengan Program Powerpoint secara mandiri dibawah bimbingan tim pengabdi. 
Dapat disimpulkan bahwa secara umum peserta pelatihan memahami konsep dan materi yang disampaikan pada pertemuan sebelumnya (pelatihan tahap pertama dan kedua), sehingga mampu menerapkan pengetahuan tersebut dalam slide presentasi yang dibuat oleh masing-masing peserta. Beberapa guru, terutama guru senior, ada yang kurang familiar dengan program PowerPoint. Di sisi lain, dari ketidaktahuan itu kami sebagai pemateri menyadari bahwa semangat para guru untuk membuat presentasi multimedia patut diapresiasi. Dari sama sekali tidak tahu menjadi sedikit tahu dan kemudian tahu merupakan hal yang tidak mudah. Akan tetapi para pengajar di lembaga Yayasan Al Yasini Pasuruan menunjukkan bahwa mereka mampu melakukannya dengan sangat baik.

Hasil presentasi untuk selanjutnya dikumpulkan sebagai arsip dan beberapa diantara presentasi yang bagus diperbaiki kembali dan dijadikan template untuk digunakan dalam presentasi riil saat kegiatan belajar mengajar.

\section{KESIMPULAN}

Berdasar hasil pelaksanaan kegiatan pengabdian kepada masyarakat ini dan uraian pembahasan di atas, dapat disimpulkan beberapa hal sebagai berikut:

1. Pelatihan ini memberikan beberapa materi yang terkait dengan upaya meningkatkan kualitas pembelajaran dengan pemberikan pengetahuan mengenai pemanfaatan Program Powerpoint untuk membuat media pembelajaran yang inovatif dan interaktif.

2. Materi yang disajikan dapat diterima dan dipahami peserta dengan baik. Jumlah peserta yang sebanding dengan jumlah pengabdi menjadikan pelatihan ini menjadi lebih kondusif.

3. Kegiatan berlangsung lancar, tepat waktu dan sesuai dengan yang diharapkan dan para peserta dapat berkomunikasi dengan para pembicara dan peserta lain dengan baik.

\section{UCAPAN TERIMAKASIH}

Ucapan terimakasih saya sampaikan kepada lembaga Yayasan Al Yasini Pasuruan yang mendukung berlangsungnya kegiatan penelitian dan pengabdian.

\section{DAFTAR PUSTAKA}

Bovee, Courland. 1997. Business Communication Today, Prentice Hall: New York.

Brown, H. Douglas. 1994. Principles of Language Learning and Teaching, Prentice Hall Regents: New Jersey.

Avis, Ben. 1991. Teaching with Media, a paper presented at Technology and Education Conference in Athens, Greece.

Elliot, Stephen N et al,. 1996. Educational Psychology, Brown and Benchmark: Dubuque, Iowa.

Hubbard, Peter et al. 1983. A Training Course for TEFL, Oxford University Press: Oxford.

Hunter, Lawrence. 1996. CALL: Its Scope and Limits, The Internet TESL Journal, Vol. II, No.6, June 1996, http:/www.aitech.ac.jp/ iteslj/

Idris, Nuny S. 1999. Ragam Media Dalam Pembelajaran. A Paper presented at KIPBIPA III, Bandung. 